Portland State University

PDXScholar

$5-1-1971$

\title{
A demographic study of transracial adoptive parents
}

Patricia Lee Hall

Portland State University

Follow this and additional works at: https://pdxscholar.library.pdx.edu/open_access_etds Let us know how access to this document benefits you.

\section{Recommended Citation}

Hall, Patricia Lee, "A demographic study of transracial adoptive parents" (1971). Dissertations and Theses. Paper 703.

https://doi.org/10.15760/etd.703

This Thesis is brought to you for free and open access. It has been accepted for inclusion in Dissertations and Theses by an authorized administrator of PDXScholar. Please contact us if we can make this document more accessible: pdxscholar@pdx.edu. 


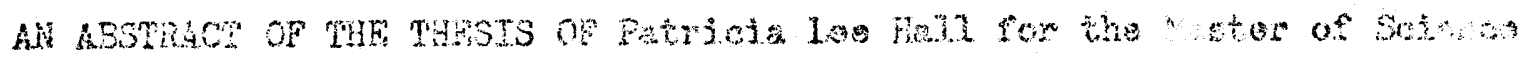
in Psyohology posented ing $13.29 \%$.

Titse: A Domographe study of Pranswatel Adoptivo Paronts. APROVE ET MPRRS OF THF TASTS COMTTEA:

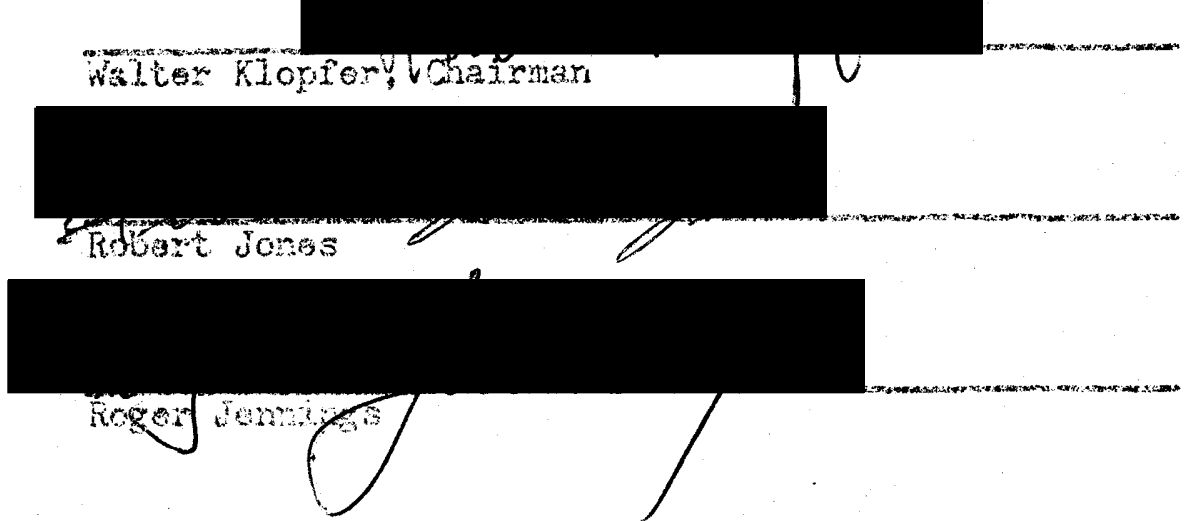

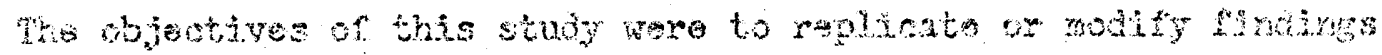

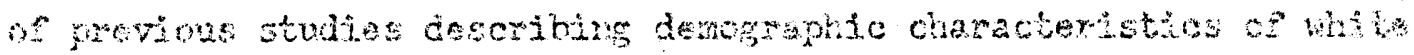

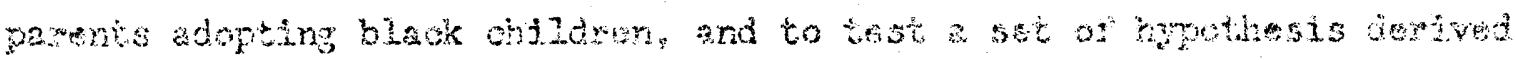

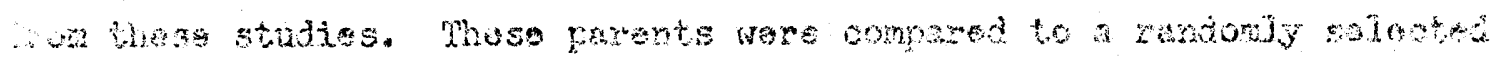

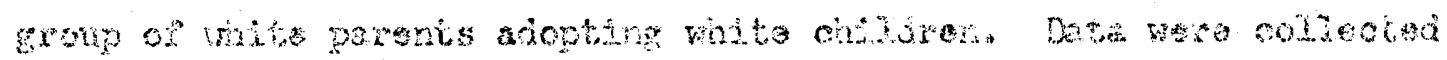

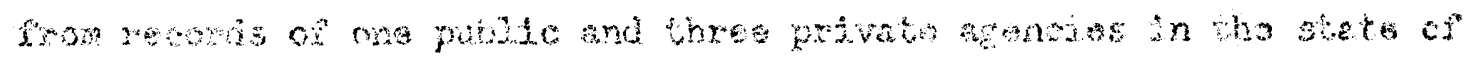

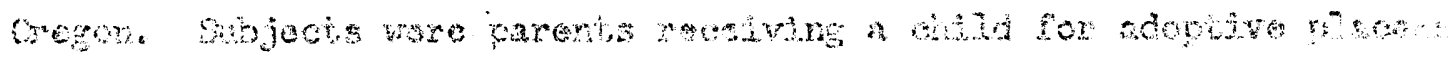

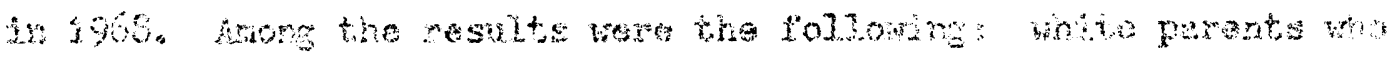

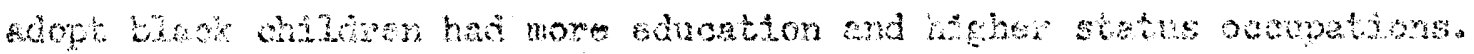

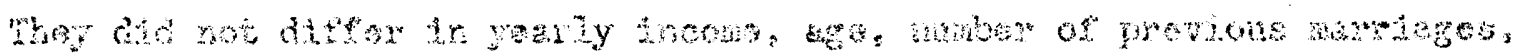

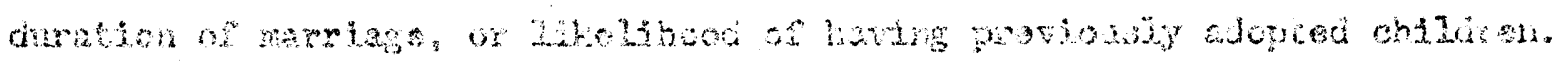

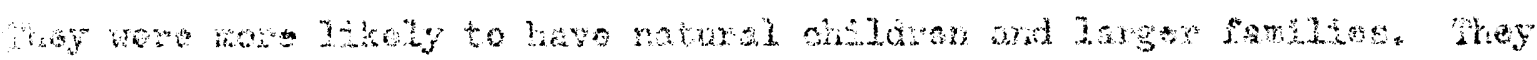

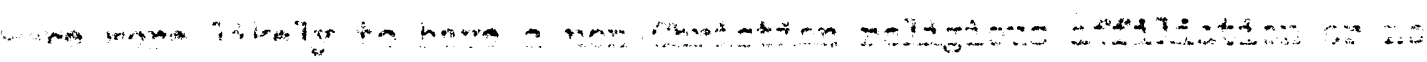


roligious affiltation, but contary to expectedion, they wero sow by the ageney caseworkers as nore jnvolved in religlous activity. 
A DEMOGRAPHIC STUDY OF TRANSRACIAI ADOPTIVE PARENTS

by

PATRICIA LEE HAIL

A thesis suontted in partial fulrillment of the raquirements for the degres of

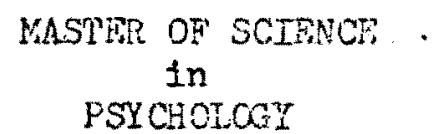

PSYCHOLCSI

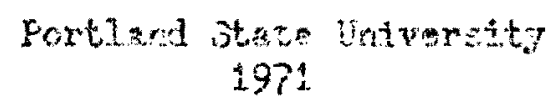


TO THE OFFICE OF GRADUATF STIDIFS:

The nambers of the Comittee approve the thesis of Patricia

Loe Hall presontod May 13, 1971.
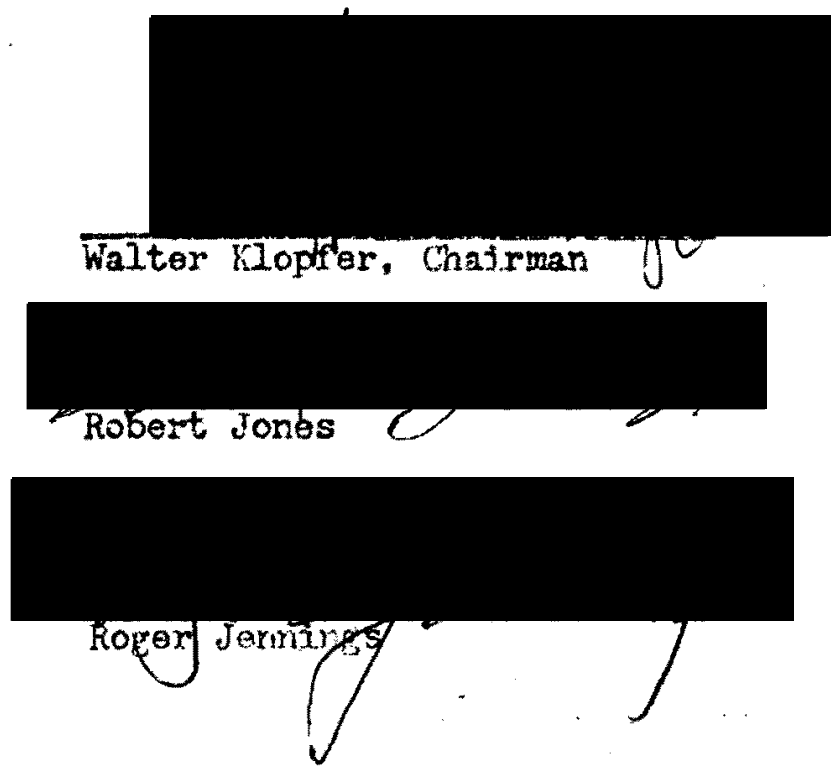

APFROVF:

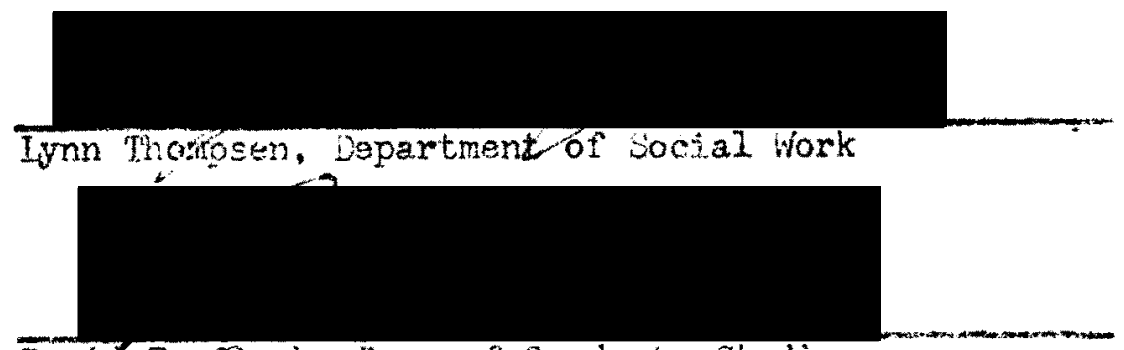

David T. Clark, Deas: of Craciuato Studios

May 13, 1971 


\section{ACKNOWLEDG FMENTS}

This study is the result of the efforts of many people. I am indebted to the devoted staffs of the agencies involvod and owe much to the encouragement, advice, and active help of Mrs. Vinlet Smith, of Iultnomah County Adoption Services; Barbara Davia, of th Stato Wsifare Sorvices for Children; Mrs. Fistor Stimmol of the poys and Gists Aid Society; Orville Garrison of Waverly Chliarurts lione; Horo Hanson, or Albertina Kerr Homes; and Miss Clair Jackson of Catholic Farily Services. Without their cooperation, guidance, and ieboxs, this study nould not have been possible.

Secondly, I wish to thank tho mombers of comittes: [r. Robert Jones, whose technical assistance was so essential; Do. Roger Jennixgs, whose fresh and insightful comments added so much to the forialation: of the dosign; and especially to my chairman, Ir. Waltor Kople: wiros enduring patjence and porceptive analysis helped zmaasinabje to ciarjfy the issues at stake. 
TABLF OF CONTENTS

PAGS

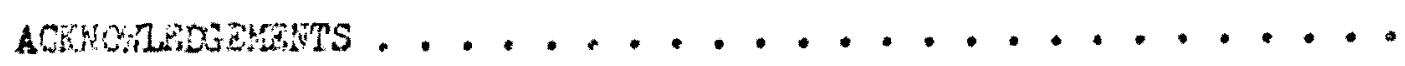
$1 i 1$

LISE of RAJLES ........................... $\boldsymbol{v 1}$ CHAPQER

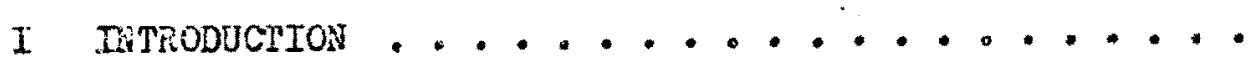

Purpose and F*ovalence of Adoption........ $\mathcal{L}$

Changing figenry polictes . . .........

The Spectal Stuation of the Elack Mildren . .

Transracial Asoption of kacic Cinjuren by White

Perents..................."

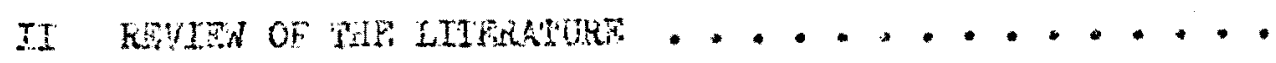

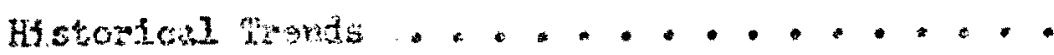

Eany sudiat ..................

Whate Couplea Wto Adopt Back Chiidron . . . . .

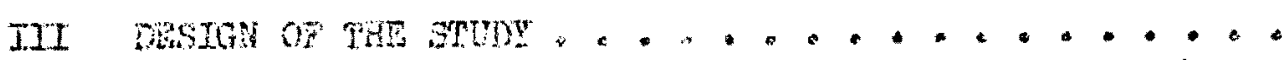

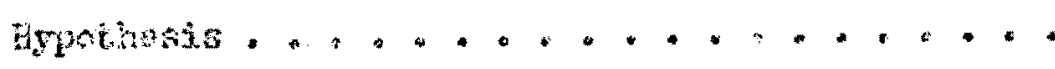

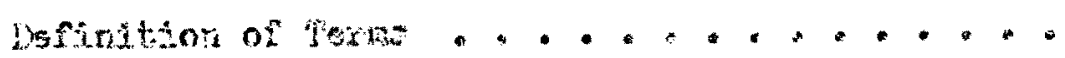

Selaction of tho somodos.............

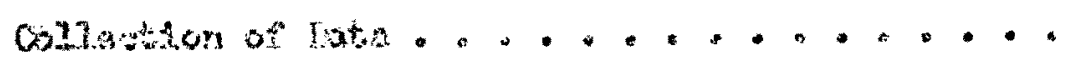

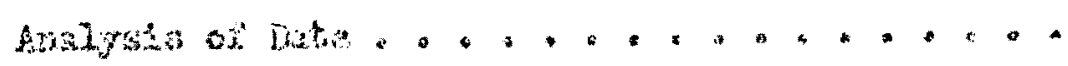

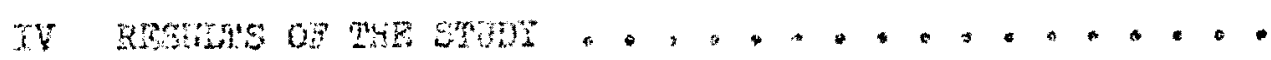

Eorector: ..................."

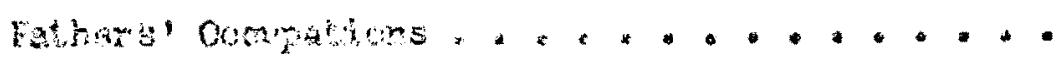


CHAPTER

Mothers" Occupations .............. 24

Famly Income ..................... 25

Age of Adoptivo Paronts . . . . . . . . . 26

Previous Marriage ................. 26

Duration of Present Marriago .......... 28

Children in the Home Prior to Placement . . . 2.8

Religious Affiliation ............. 30

Percelved Religious Involvement . . . . . . 31

Children Píaced in Adoptive Hones ....... 32

Childron Awaiting Adoption .......... 33

V DISCUSSION OF RESULTS ....................... 36

Iriplistions of the study .......... 35

Limitations of the stady ............ 33

Recomendations for Further Study ....... 39

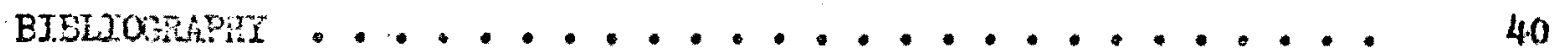




\section{LIST OF TABLES}

TABIE

PACE

I Studies of White Couples Adopting Black Chtldren . . . 14

II Education of Adoptivo Parents .............. 22

III Occupations of Adoptive Fathors ............. 23

IV Adoptive Mothers' Occupations . . . . . . . . . 24

i Annual Family Income of Adoptive Parents . . . . . . 25

VI Family Income Compared to Combired Samplo Mean . . . . 26

VII Age of Adoptive Parents . . . . . . . . . . 27

VII Agos of Adoptive Parants Compared to Combinsd Group Itean or $31.5 \ldots \ldots 27$

IX irumber of Years Adoptive Couple Married . . . . . 28

$X$ Number of Children Prion to 1968 Piacoment . . . . . 29

XI Prosence of Adopted Cilldren Prior to Placenent . . . 29

X.rT Presence of Natural Chiliren Prior to Placement . . . 30

XIII Religious Affiliation of Adoptive Parents ....... 31

XIr Christian and Non Christisn Affiliation of Adoptive

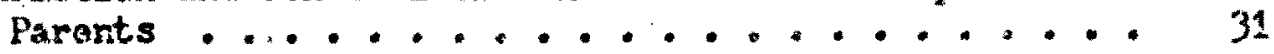

XV Caseworker's Estimato of Couple's Relifeious Imolvarent. 32

7VI Conldren Placed for Adontion in 1968 by Age. Agenty and Racial Group ................. 34

YVII Gildwen Akstirig Aioption in Privat Agoncias.

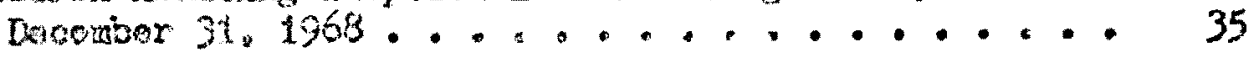




\section{CHAPTER I}

\section{INTRODUCIION}

\section{PJRPOSE AND PREVALFNCE OF ADOPTION}

Aloption has been practiced since ancient times. One of the earlfost krown adoptions was that of Sargon, King of Rabylonia, circa 2800 F. C. Fgyptians, Babylontans, Greeks, Romans, Indians, and Chineso all practiced acoption. In early times, adoption served the needs of the parents. In many ceses it was necessary to havo a malo heir to continue the family line and hold property. Sometimes having a large family eninanesd one's chances of being elocted to office. Most importantiy, in some cultures, adoption was the key to heaven, whose gatos openes only to thoss with sons (Kadushin, 1967).

Todey adoption is considered primarily as 2 means for providing horts for children in noed of thom. Logisiation and professional adoption standaris sesk to insure the protection of all involved-mthe natural parents, tho acoptive parents, but first and foremost, the adopt.j. childwen. Dswilopmental psychology has contributad a good deal of resoerch to support the psychoanalytic notion that the oarliest yoars of Iffs are oferiolmingly signiflcant in deternining tho later functionIng of the alult. The importance of an oarly, close, continuing relationship with carstakgs-parent cannot bo overomphasized. Although alternato mathoris of inzaling, children throughout infancy and childhood have sonetines shown favorable outcomes, the mothod of cholce still appoars 
to be the nuclear fantly, and the best possiblo solution for parontloss childron appoars to be adoption.

Within our own country adoption first served the needs of parents, and only later evolved into an Institution devoted to the noeds of children. In Colonial America orphans were bound out as apprentices or bound servants, oarning thelr way oconomically; somotimes at terriblo costs to themselves. Farly laws provided for little more than public recording of the legal ties, but around the turn of the certury. logism lation caris to bo increastngly designod to protect, tho children (Kaciushin, 1957). Waiting periois have becone a roguirad part of the procodin in most states, and welfaro dopertmonts have bost dracted to angage in investigational activitios to detormin the suitability of actptive parencs.

Acencies have com to participato in an increasing share of the rosponsibility for supervising selection and oarly adjustment. The advantages of agency placoment have becono more widely accepted by the public as shoin by the rising proportion of adoptions arranged by agencies. In 1951. agency and indepondent adoptions wero nearly equal. in numbers, but in 195?, agencias arranged soventy-one percent of a.1 adoptions (US H. R.W. , 1969).

More children are belrig adopted each year. The Children's Bureau reports an increase from 91,000 in 1957 to 121,000 in 1962 to 142,000 in 1965. to 158,000 in 1957. Of the 158,000 children adopted in 1967 , about 83.700 (53\%) woro adoptod by relatives, and 74,300 (147\%) by non-relativos (US H.F.W., 1959). Kadushin (1967) has pointed out

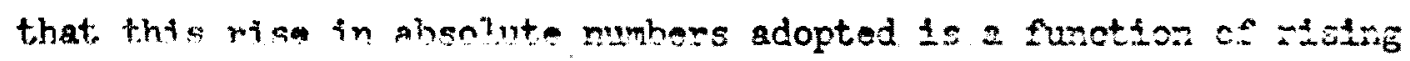


population, and that, in fact, the annual adoption rate per 10,000 childran under twenty-one years of age romained quite constant at fourteen or flitioen, from 1951 through 1961.

\section{ChangIng agBnCY POLTCIES}

The quality of homes selocted for adoptive children, and the nature of the solection policies practiced by agencies, depond upon two factors. Flrst i.s the conceptual set of the responsible persons. The shift in priority from needs of parents to noeds of children to neods of both is an example of such a conceptual set. The second important factor is the oconomic fact of supply and demand. Brielard (1965) has briefly reviswed the historics]. developments in the field:

The ourliest omphasis seomed to bs on providing the ideal child. Late placement and psychological tost results wore used to make this possiblo. Thon the emphasis was changed to selection of the nearly ideal applicants from a large supply. Now there are attoints to pleco childron with all possible special probloms and efforts to rocruit adoptive parents, including those who are by no means ideal. (Quoted from pago 62).

Durlng early times, there wero many children available, and children wers an economic assac. Adoptive parents could afford to be seloctive, and shoptive axtericios surved those wishes. Childron were held in instituliomsi cure, or loss commonly, foster caro, as long as was necessary to ssomiah tloir suitability. Children with "probloms", characteristies such as peidel diffarenco or physical or mental handicaps that diminished thoir canaricy to mast parental noeds, wero declared "unadoptable" and

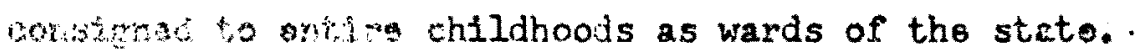


As the second period of attitude change occurred, there were fower healthy "uncomplicated" Caucasian infants than there were eager applicants. The t.ask of the caseworkers then became sifting the best possible homes from the abundance. Standards for adoptive parents were very high, but also sometimes arbitrary, rigid, snd restrictive. Many people who might have been fine parents rere excluded from the adoptivo experience because they did not conform to a narrow stereotype of ideal parenthood. Maas has composed a modal profile of successful adoptive couples, who, he said, "In each community wore remarkably altke" (Maas, 1960). This couple were in their mid-thirties, with no medical problems except a clear infertility roport. They had been marriod ten years, neither married before, both white, Protestant, belonging to and active in the samo church. They wero both high school graduates and had a modest but dependable income, and owned their own home. They were attached to family and thoroughly nomal in behavior, if somewhat more controlled by principle than average. Adoption would provide them with a first child, rosembling them as much as possible.

All this changed in the sixties, as adoption agencies noticed a change in the ratio of adoptive paront applicants to arailable children. Both groups havo increased over the gears, but the relative ratio has changed. Tinis chango was first documented by Lydia Hylton, of the Cild Welfara Isazue of America. Hylton sent questionnaires to 1244 agencies, nationisds, and recoived 672 replies. The findings of this study, and a similar follow-up study (Rtday, 1969) revealed a relativo decline in nourelative agency adoptions and applications, compared to the iavidiy risine number of children availahia. The ratio of applicatens 
por 100 avajlable children declined from 158 in 1958 to 129 in 1961. to 104 in 1967 (Hylton, 1965; Rlday, 1959). The latest Child Welfare League study (Grow, 1970) suggests that the relative number of applicants to children is now beginning to increase again. This study has shown that for every 100 white children awaiting adoption there are. 116 potential homes.

Two factors seem to be operating in this shift in trend. One is the increased incidence of illegitimate children being kept by their. natural mothers, rather than being released for adoption. Second is the result of changing agency policies brought about by the pressure of the disadvantageous (to children) ratio.

Reduction in the relative number of applicants made necessary a reessessment of the selective process utilized by tho agencios. The Hylton study compiled a list of chenges undertaken by responding agencies:

Relaxation of, or more flexibility regarding, regulations pertaining to the age of the applicant. paymont. A change $i_{1}$ the amount of foe or method of

Placement of children with couples who have other adopted children. More flexibility regarding the number of years applisents have been married. Floxibility in plactrg children with couples who have chtldren of their own.

The use of homes in which the adoptive mother works, or accepting this after an "adjustment period". Were flexibility with regard to the "matching" of retigion. Entirely omitting or being more flexible with regasel to proof of infertility. (Quoted from page 386)

The eligtbiltivg requitrements of agencies were reviewed by the Child inglure Lague of America in 1954, and updated by Brieland in 1959. These standards waxe reflected in the Chlld Welfare League 
Standards for Adoption Service, published in 1959 and revised in 1969. which serves as the foundation for most agencies' policies, and as a guide for professional activitios. Changes in the direction of greater flexibility are apparent when the two editions of these adoption standards are compared.

\section{THE SPECIAL SITUATION OF BI.ACK CIILDREN}

The relative scarcity of hopeful parents is wuch more crucial for non-white children, particularly those with any Negro racial component. In Riday's questionnaire surrey, special attention was focused upon this aspect of the problom. These findings, based upon records from 1957. showed that for each available 100 white children there were slightly more than 100 applicants, whle for each 100 available nonwhite children there were only 60 non-white applicants. The most recent Child Welfare League study (Grow, 1970) has shown that for each 100 non-white children awasting adoption, there are only 39 prospective beras, compared to the 116 potential homes for every 100 white children. Non-wite statistics fnclude both black and other non-white groups, so the situation of black chjidren is underestimated by these figures (see ditensston below).

Provious studias have shom the attrition rate anong black applicerts so bo very high (Fenshel, 1967). Recruitment campaigns have been IE. *ten have not been the sigmificant variables. The key considerations, ontisud by Kadushin (1967) appar to be the insenura socjoeconomic status of the Negro people, the lack of trust, they nave in the finture. 
the residue of unpleasant past exporiences with agencies, and the unrealistic application of selection standards to blacks that are more appropriate for whites. Studies have shown Negro applicants to be older. more often divorced, with more working wives and less proven infertility (Fanshel, 1967; Woods, 1962). Secondly, even with these discouraging factors, non-whites, when financially able, already edopt at a higher rate thar whites (Herzog, 1965). There simply are not enough potential non-white fanilies to absorb the available nonawhite children.

This situation is especially crucial for Negro children. Survey data from 1968 shows that state and national statistics, which do not separate Negro from other non-white races, misrepresent the plight of the black child. Opportunity, a Portland, Oregon group, conducted a survey which they estimated to account for botweon 70 and 80 percent of placements of non-white children made in 1968. Of these placements surveyed, half were of black heritage and half from other non-white races. Since Negroes outnumber other non-white races by ten to one, it is the Negro child who is being omitted from the groups that comprise national statistics on non-white adoptions.

Whilo the agency survey findings on unplaced Nogro children are grim, it has beon estimated (Isaac, 1965; Riday, 1967) that the Negro children ufficially available for adoption represent only a small proportion of those potencially available if hones could be found for them. Issac has given an exrmple to constdor:

In Detroit, for example, it was reported in the Detrojt News of February 23, 1964, that the 99 Negro children legally free for adoption vore only a small proportion of those really needing adoptive homes. The court had over 1.500 child ron in temporary custody who could readily bo 
freed for adoption, but no agencies bothered to go through the necessary court procedures since there was no prospect of finding adoptive homes for them. A similar situation exists in large cities throughout the courtry. (Isaac, 1965. page 122).

Riday (1967) has reported that in 1967 thero were only slightly more than one million non-white husband-wife famjlites, age 25-44, with incomes of $\$ 5000$ or more, in the United States. With 176,000 non-white illegitimate births that year, each child had a ratio of only six possible non-white adoptive families potentially aveilable, even if all these families had been eligiblo in other ways.

Recruttment plans, then, even when successful, simply encourage an increasing supply of childiren who tend to balance out the gains of the recorded pool of unplaced but legally free children.

If would seem therefore, that if homes are to be found for the 40,000 to 80,000 Hezro childron that the Children's Bureau estimates to be potentially available for adoption (Fiday, 1969), agencies must look to white parents who will adopt Negro children.

\section{TRANSRACIAI ADCFTION OF BLACK CHILDREN GY WHITE PARFNTS}

Mnccuraged by the satisfactory adjustment of children of other minority races placed in white homes, agencles began placing black children in white homes beginning in 1958, with the Children's Service Centro of Montreal, Canada, leading the way. Their successes were an wncoursgine example, and in the early sixtios plicements of black children with wite parents were made in several states by the Gijdren's Home Sociaty of California, the Boys and Girls Aid Socjety of Oregon, the 
Chicago Child Care Society in Illinois, and othors (Mitchell, 1959). As these early placements were accepted by communities, the agencies involved published the news of their experiences, encouraging others to make similar attempts. A survey of transracial adoption in 1968 and 1969. conducted by Cpportunity (1970) showed that the majority of all known adoption agencies were placing black children with white parents. Opportunity estimated that by 1969. 1.500 anildren had been so placed, a figure comprizing a sigriffcant proportion of the adoptive placensents of black children. In 1968,733 children, or 23 percent of a?l aiopted black children, were placed in white heros. In 1969 that figme jumped to $1,44 r^{\circ}$ children-..one third of all placements of black children. This represented an 81 percent increase in the number of black children placed with white families (Cpportunity, 1959, 1970). Thile theso changes represent important modification of trend and custom, it is only a beginning in terms of the actual proportion of children placed to children awaiting placement. 
CHAPTER II

RFVIFW OF THE IITERATURF

The newness of this area of transracial adoption has given rise to a good deal of interest in those parents who are willing to accept black children as family members. In earlier times such placements would not have been possible, due to agency restrictions that required the racial and physical matching of parent to chlld. Iong held assumptions and policies are difficult to overcome. It has been the function of adoption research studies to dispel some of these cherished stereotypes, and thus to enable agencies to evolve more flexible policies which will better meet the needs of a wide variety of adults and children. One such study was that of Henry Mas (1959) whose careful examination of parents who adopt hard-to-place children produced a recommendation that agencios widen their concept of eligibility to take advantage of the greater tolerance within the adoptive parent population than that being utsized:

\section{HISTORTCAL TRENDS}

Intil just recently, black children were lumped with other hardtombseo olildren, and comparative studios simply examined characteristics of thos rarents accopting the children with any problems of any kind. whethar racial, emotional, Intelloctual, social, or physical, comparing then to crepters of healthy white infants. The selection process for 
both groups involved much more than the tolerance and interest of the applicants. To a large extent, agenctes selected parents according to their om preconceived notions of what constituted elfgibility for a particular child's potential parent. For example, as long as there was a surplus of applicants for hoalthy, Caucasian babies, very homogeneous group of socially modal, conservative, well-establiched parents could be chosen by the agencies. An entirely dj.fferent selection of requirements could be applied to the second group-those willing to "settla" for the child with problems. Age limits could be extended, Income requirements relaxed, former marriages overlooked, infertility proof waived, and the adoption fee omitted.

The decisional autocracy of the agoncies came to an end when the supply of children exceeded the supply of epplicants in the early 1960's. Forced to either revise selection policies or deny children homes, the agencies mado radical changes in the direction of greater floxibility. With so much greater acceptance of difference by agencies, the group composition came to be influenced far more by decisions of parents, and reflected much more eccurately the kind of people who themselves wished to adopt various kinds of children, rether than solely the kinds of peoplo the agencies thought should be matohed to these children.

\section{FARLY STUDIES}

Therly papers have attempted to describe adoptive parents as a group. An early paper by laahy (1932) outlined a profile of adoptive parents generally, describing them as childless couples, older than

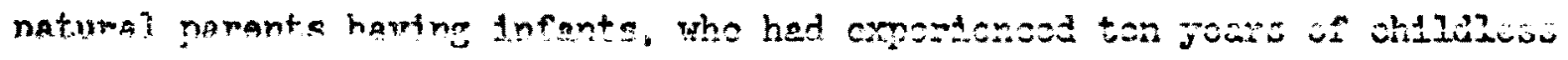


marriage before adopting. They ware very likoly to be native Americans. This study utilized no comparison of subgroups.

Shapiro (1954) has compiled a 14st of parental characteristics, as they were determined by the selective influence of agency policies. Characteristics required by the egencies wore physical and emotional health, marriage, financial stability, age below a maximum, minizun duration of marriage, religion, and infertility.

One of the earliest attempts to compare parents adopting infants wh th parents adopting older, handicapped, or minority race children was that done by Mass in 1959. In this cross-cultural study, case rocords were selected randonly from the chosen communities. The basis for choosIng conmunities was not described. In this comparison, Mass found parents accepting older, complicated children more often from lower occupational status couples.

Shapiro (1957) has also studied children with "special noeds", chtidren with physical or emotional disabilities, chtldron whose parents had such difficulties, and children of minority. races. He has described the parents who adopt such children as having incomes under $\$ 4,999$ (70 percent), boing dividod in father's occupation, and being about forty porcent college greduates.

In 1962, Kadushin described parents of "hard-to-place" children as Iraking in eligibility. The most frequent defleiency with respent to agency standards was a tendency to be abovo forty years ofe age. othor problens included mixed-religion marriages, mixed-race marriages, history of divorce, other children in the home, or hasilth problams.

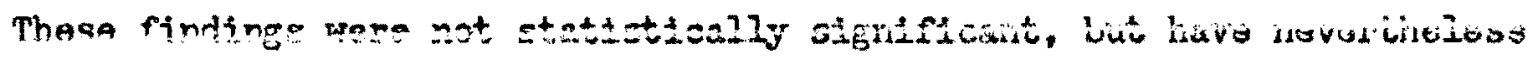


boen influentide in picturing adoptive parents of children with eligibility problems as themselvos having elfgibllity problems.

III. WHITE COUPEES WHO ADOPT BLACR CHILDREN

Pepper (1966) has reviowed a number of unpublishod studtes of parental characteristics of transracial adoptivo parents. These studies that spaciflcally focus upon adoption of black childror, and several related studies, are summarized in Table I.

Studies that have separated the black childron from other special grcups have generally agreed that the socio-oconomic level of their adoptive parents is higher than other adoptive parents. It has been suggested that these families are nore likely to have childran. Rovorts do not agree on the relative ago of this group. These-parents are orten described as humanitarian, but. sometimes ss being more involved in organized church activities and sometimes as being iess involved in church. 
TABLE I

STUDIES OF WHITE COUPLES ADOPTING BLACK CUILDREN

\begin{tabular}{|c|c|c|c|c|c|c|}
\hline Spoers 1962. & higher & higher & higher & sams & & \\
\hline Rosktes 1963 & above averago & above average & abovo average & & most & \\
\hline Marror 1964 & woll educated & & professional & & yes & active \\
\hline Sellers 1969 & collage tratne & & & & jes & $\begin{array}{l}\text { lacking } \\
\text { affliletion }\end{array}$ \\
\hline Priddy 1970 & & & mostly profes: & stonal & & \\
\hline
\end{tabular}


Early studies that have combined heterogenecus groups or reported instgnificant findings have been influential in creating a picture of parents who accept disadvantaged children as being themselves marginal people. Iater reports, separating black children from other special children, have done much to change this stereotype of the "second rate parent for the second rate child". Unfortunately. fer of these reports contain statistical tests of significance, and those that de have usually utilized mixed groups. Since the situation is so different for a black child, statistical studies deroted to this spocial group are urgently needed.

Agercles are vitally concorned with such reports, because they poirt the way to go to seek potential homes for children under their charge. nowirg the kinds of parents who have wanted biack children in the past expedtites the screening process for couples who apply, and also provides a base of general information useful in recruitment campaigns. Racruitiment is a new thing. for agencies, but it is now bocoming accepted as absolutely necessary if old myths about the difficulty of adoption and the impossibji. ity of adopting transracially aro to be expioded.

A sscond uregnt need for such studies fis ralated to the soctal destrabitity of assuming such a rolo in the face of early steraotypes. Potential parents may not wish to be identified with early doscriptions of "marginal" parents who accept children with problems. The discovery that for many highig qualifict couplos transracial adoption is a first choice rather than a comporise can allow both agenctos and prospective parents to abandon defengtve postures.

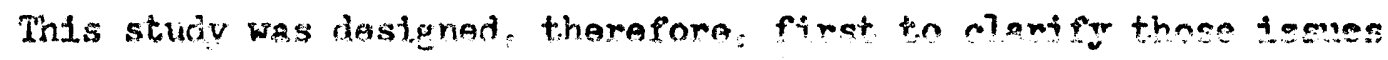


In dispute, and secondly to provido statistical evaluation of those contentions generally agreed upon, but reported in uncontrolled or informal studies. 
CHAPTER III

DESIGN OF THE STUDY

\section{HYPOTHFSES}

Tho review of the literature brings a number of demographic characteristies of those white parents who adopt black children to our ropeated attention. A number of previous studies bave pointed up the differences between such parents and those who have adopted within their own racial group. The direction of these differences is not agreed upon from early to late studies, in the case of socioeconomic factors, or even within current writing, in the case of those factors related to fantily and roligion. From these differences and controversies, the following hyfotheses have bean formed:

1. White perents whe adopt black children will have more education than white parents who adopt white childron.

2. White parents who adopt black ch11dren will have higher incomss than white parents adopting whito childron.

3. The whtte adoptive fathers of black children will hold higher status occupations then the white adoptive fathers of white children.

4. The whito adoptiro parents of black children will be younger than the white adoptive parents of white children.

5. White couples adopting black chlldren will bo more lfkely to havo children, oither adopted or natural, and they will have more children. 
6. White couples adopting black children will be seen by the agencles' caseworkors as jess Involved in church activities than white adoptive parents of whito children.

\section{DEFINITION OF TERMS}

To test these hypotheses, two samples of aduptive parents were selected. The first sample was composed of whito couples who had adopted a child who was Negro, or who was part lagro. For tho purposes of this study, matred-race children wore classified es black if they had any Nogro component, without regard to other racial components. These parents comprised the transrac1a] group. The comparison group consisted of Caucasian paronts adopting Caucasian children. This group was designated as the control. group. A couple was designated as an adoptive couple if an adoptive placement was made. The operational defiritions of both groups included for use as subjects any single unmarried adoptive parents, since oregon law and agency policy accepts such adoptive applicants if they are well qualified in other ways. However, no such adoptive placements were made within these groups in 1968.

\section{SELECTION OF THF SAMPLES}

In Oragon, adoption services ara avaliable from one public agency, the Cild welfare Commission, with branches in each county, and stx pritate gencles: Albertina Korr Homes, tho Roys and Girls Air Soctety, Catholice Fanjly Services, the Holt Adoption Agency, Jewlsh Family Servicos, and Wavorly Children's Homen The Holt Agoncy speciallzas 
In Importing Asian ehildren for placement in American fantlies throughout the Inited States, and was not, therefore, involved in the kind of placements this study attempted to examine. Fach of the other agencies was contactad, and in overy case generous cooperation was extended. Durlng 1968, black children were placed with white parents by the Child Welfaro Commission, Boys and Girls Ald Society, Catholie Family Sorvices, and Waverly Chjldren's Home. In order to obtzin a large enough group for comparison, the entire group of white parentwblack child placements was neoded. The entire sample from the private agencies and nearly all from the pubic agencies were pooled to form a study group of 36 farilies. The control group was randorly soleoted by tho partictpating sgencios in proportions matching tho composition of the transracial group.

\section{COLIECTION OF DATA}

Confidentiality of adoptive files is protected by law in Oregon. It was necessary, therefor, to transfor the data of interest to tab ulation shests that contained no ldentifying information. This operation had to be parformed by those porsons employed by the agencies and heving legal scosss to the flles. Tabulation sheets wero provided that allowed for recording the following information for aach subject couplo: educat10n, sincone, occupation, age, religlous preference, perceived neltgions involvexent, previous marriages, duration of marriage, and othas childier. whthin the ramily.

\section{v. ANALYSTS OF DATA}

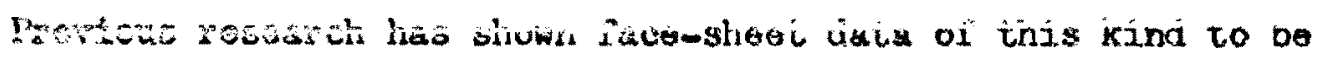


highly roliablo (Parten, 1950). In order to provide the maximun amount of descriptive information, data was converted into percent values in those instances in which it appeared to render tho sample numbers nore mearingful. In order to test for statistical differences between groups, deta were categorized and tested by means of chi square. Within the limits imposed by statistical analysis requirements, data were grouped to provide maximum differentiation and usefulness. Wherever posstble, categories were ẹstablished beforehand using long-established guidelines, such as the Bureau of Census categories, as a model, and these categories were then combined as demanded by the numerical nature of the statistical anolysis. 


\section{CHAPTER IV}

\section{RESUYTS OF THE STUUY}

\section{EDOCATION}

Both groups had achieved educational Jevols above the national median of 12.2 yoars (Stat1stical abstracts, 1970). Nationall.y. 44.3 percent. of whito adults iajl to achieve four years of high school, and only 11.2 percent achleve four or more years of college. None of the transiacial group failed to complete four years of high school, and only soren, or 9.7 porcent of the control group had loss than that much ed. vcation. The transracial group containod forty-four parents with a college degres or more, ard the contrul group contained twenty-two (61.2 porcent and 30.6 percent respectively). In the transracial group the average years education for nothers was 14.9 ; ror fathers it was 16.5. The cortrol paronts average 13.4 years education for mothers and 14.0 yesirs for the fathers.

Riventional estegories of both groups aro showr in Tablo II.

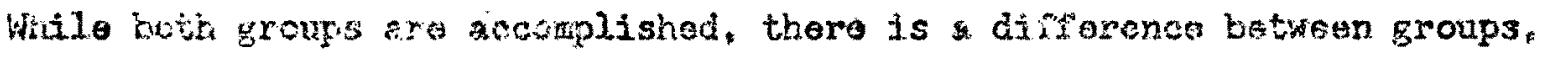
stutsetion lly significant at the 0.01 levol, in the diration predictad bo the lypotinesis. The parents adopting black chilaren had nore educat lon than those adopting white chlidren. 
TABLF: IT

FDUCATION OF ADOPTTVF PARENTS

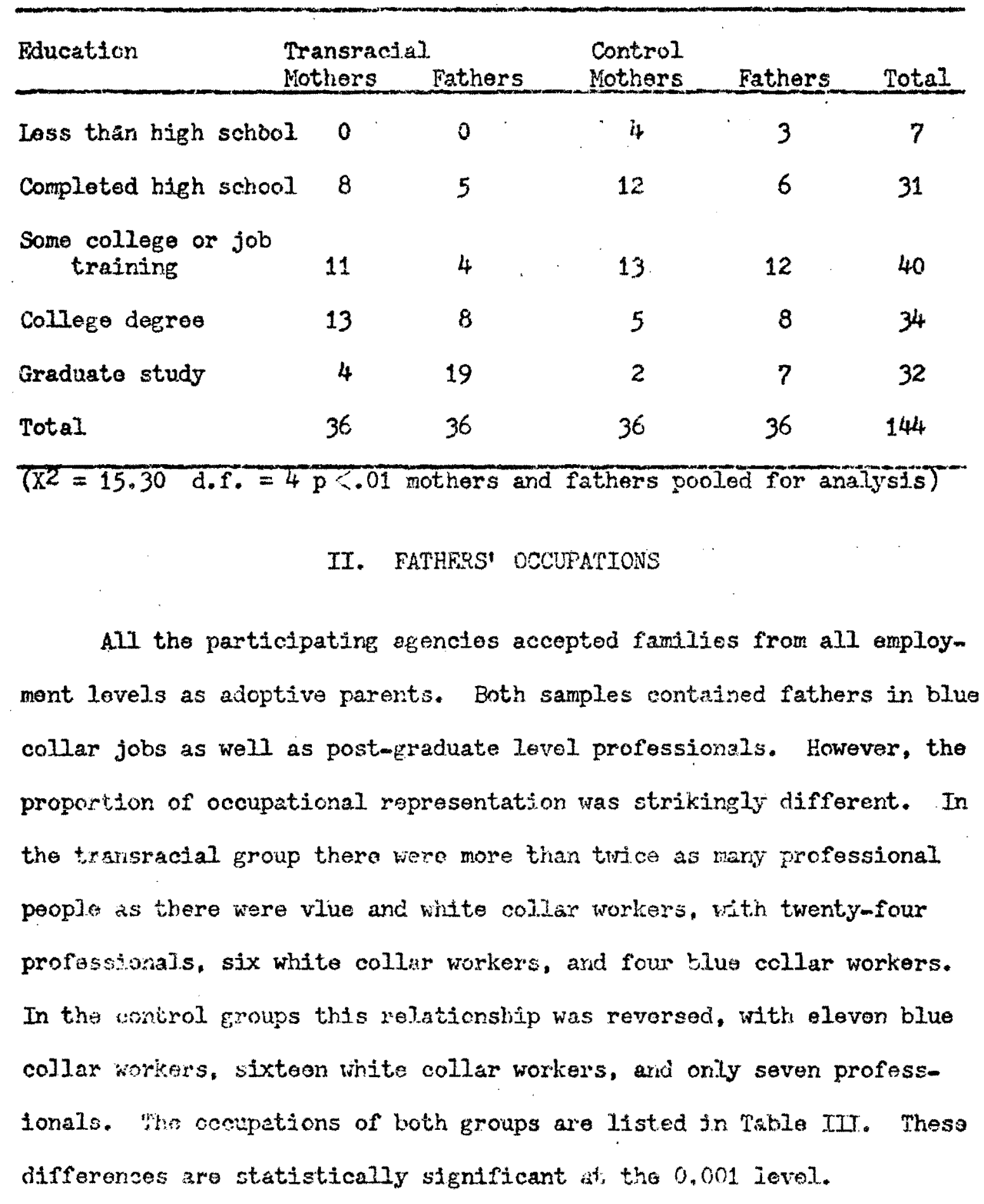


TABIF III

OCCUPATIONS OF ADOPTIVE FATHERS

occupation Transracial control Total

1. Blue collar group

Unskillad labor

21

3

Skilled, manual.

2

10

12

2. White collar group

Clertcal. sales. tochnicians

4

8

12

Adudnistrative

smajl business owners

2

8

10

3. Managerial and professional

group

Businoss managers

0

1

1

Higher executives

0

0

0

Professionale at

bachelor's level

8

4.

12

Professionals at post-graduate lovel

16

2

18

4. Unclassified grapp.

Students

1

1

2

Unknown

1

1

2

Total

36

36

72

$\left(X^{2}=19.44\right.$ d. $\left.x_{0}=2 p<0.001\right)$ 
The fathers' occupational choices appeared to reflect very dfvergent intorest.s. Whereas fifty-three percent of the control group cbose jobs of a commercial. nature, ranging from salesmenship to bankaxamining. only eight percent of the transracial fathers did so. The majority of these fathers, seventy percent, chose work in academic, scientific, religious, aesthetic, or social areas. The most frequently mentioned occtipation among the control group was that of salesnian (mentioned by four fathers); the most frequent cccupations of the transracial group were teaching (seven) and ministry (six).

\section{MOTHERS' OCCUPATIONS}

The majority of both groups of mothers were identified as full. time housewives. Thirty-nine percent of tho transracial adoptive mothers worked. The most frequent fob was that of teaching or assisting teachIng. Other mothers were nurses or secretaries or a variety of other things. The differences in occupations between groups wore not statistically sigrificant. They are show in Table IV.

\section{TABLF IV}

\section{ADOPTIVE MOTHEKS' OCCUPATIONS}

\begin{tabular}{|c|c|c|c|}
\hline Oceupation & Transracial & Contro]. & Total \\
\hline Housewives & 26 & 22 & 48 \\
\hline Other jobs & 10 & 14 & 24 \\
\hline Total & 36 & 36 & 72 \\
\hline
\end{tabular}


IV. FAMIIY INCONF.

The transracial group reported an anrual family income of $\$ 9850.00$. The roported annual income of the control families was $\$ 11,213.77$. The averago reported arnual income of all families was $\$ 10,213.17$. This can be compared to tho Fditor's and Publisher's Market Guide estinated income per Oregon household of $\$ 10,422$ in 1968 . Table $V$ shows the income categories of both groups. The differences are opposite in direction from that predicted, but there is no significant tendoncy for either group to have more mombers above or beiou the group nean. Table VI shows this comparison.

TABLE V

ANNUAL FAMILY INCOME OF ADOPTIVS PAESN'S

\begin{tabular}{lccc}
\hline Income & Transracial & Control & Total \\
\hline Under $\$ 6000$ & 2 & 2 & 4 \\
$\$ 6000-\$ 9000$ & 15 & 9 & 24 \\
$\$ 9001-\$ 12000$ & 15 & 10 & 25 \\
$\$ 12001-\$ 15000$ & 2 & 11 & 13 \\
Over $\$ 15000$ & 2 & 3 & 5 \\
No dats & 0 & 1 & 1 \\
Total & 36 & 36 & 72 \\
\hline
\end{tabular}




\section{TABLE VL}

FAMTLY INCOME COMPARFD TO COIBINED SAMPIE MFAN

\begin{tabular}{llll}
\hline Income & Transracial & Control & Total \\
\hline Below maan & 20 & 17 & 37 \\
Above masan & 16 & 18 & 34. \\
Total & 36 & 36 & 72 \\
\hline
\end{tabular}

$x^{2}=.36$ d.f. $=1$ (not significant)

\section{AGE OF ADOPPIVE PARFNTS}

The age of mothers in the transracial group ranged from twenty-one to fifty, with a mean age of 31.3 years. The fathors in tho transravial group ranged from twenty-two to fifty with a mean ago of 33.4 yoars. In the control group, the mother's ages ranged from twentyofour to fortyfour with a mean age of 29.5. The fathor's agos ranged from trrenty-three to fifty with a mean age of 32.t. The age ranges of these groups are representod in Table VII. The differences botween groups were not significtit, The ages of group nembers, relative to the group mean, are coupared in table VIII.

\section{PREVIOUS MARRIAGE}

Twentyonine couples in the transractal group and thirty couples in the control group had not experienced a previcus marriage for either partner. In soven of the transraclal families and six of the control families, ono or both maritul partners hac boen married to another person 
prior to this marriage. This represents no statistical difforence between groups.

TABLE VII

AGE OF ADOPTIVE PARENTS

\begin{tabular}{|c|c|c|c|c|c|}
\hline$A g B$ & $\begin{array}{l}\text { Transrac } \\
\text { Mothers }\end{array}$ & $\begin{array}{l}\text { ial.: } \\
\text { Fathors }\end{array}$ & $\begin{array}{l}\text { Control: } \\
\text { Mothers }\end{array}$ & Fathers & $\begin{array}{l}\text { Total } \\
\text { Parents }\end{array}$ \\
\hline $21-15$ & 4 & 1 & 8 & 4 & 17 \\
\hline $26-30$ & 18 & 16 & 17 & 13 & - 64 \\
\hline $31-35$ & 6 & 9 & 8 & 9 & 32 \\
\hline $36-40$ & 3 & 4 & 0 & 6 & 13 \\
\hline $41-45$ & . 4 & 2 & 3 & 1 & 12 \\
\hline $46-50$ & 1 & 4 & 0 & 1 & 6 \\
\hline Total & 36 & 36 & 36 & 36 & 72 \\
\hline
\end{tabular}

TABIE VIII

AGES OF ADOPTIVF FARFNTS COMPARED TO COMBTHED GROUP MEAN OF 31.5

\begin{tabular}{lccc}
\hline Age & Transracial & Control & Total \\
\hline Loss than 31.5 & 44 & 46 & 90 \\
More than 31.5 & 28 & 26 & 54 \\
Total & 72 & 72 & 144 \\
\hline
\end{tabular}

$\left(x^{2}=.12\right.$ d.f. $=1$ not significant $)$ 


\section{DURATION OF PRESENT MARRLAGK}

Couples in the transracial group had boen married from one to twenty-three years; couplas in the control group had been married frow under one year to nineteon years. Table IX shows the division of couples Into newly wod and long married. There was no statistical difference batween groups.

\section{TABLE IX}

NUMBER OF YEARS ADOPTIVE COUPLH MARRIED

\begin{tabular}{lccc}
\hline Years marized & Transracial & Control & Total \\
\hline Five or less & 10 & 10 & 20 \\
$5-9.5$ & 16 & 15 & 31 \\
Ten or more & 10 & 11 & 21 \\
Total & 36 & 36 & 72 \\
\hline
\end{tabular}

VIII. CHILDRFN IN THF HOMF PRIOR TO PLACFMENT

Tho major1ty of fanj.110s in both groups had childron prior to this placenent. Only 16.5 percent of the transracial group and 36 percent of the control group vere childless at the time they recelved this child. The transracial group tended to have larger familtes, with on avorage of 2.25 children compared to the control groups' average of 0.92 children. Averege fartly size rationally was 3.19 in 1969 (Bureau of Census. 1970). Tho respective family sizes aro shown in Tablo $X$. 
TABIF: X

NUMBFR OF CHIIDRFN PRTOR TO 1968 IJLACEMENT

\begin{tabular}{lccc}
\hline Mhumber & Transracial & Controi & Total \\
\hline 0 & 6 & 13 & 19 \\
1 & 9 & 19 & 28 \\
2 & 6 & 1 & 7 \\
3 & 7 & 2 & 9 \\
4 & 4 & 0 & 4 \\
5 & 3 & 0 & 3 \\
6 & 0 & 1 & 1 \\
7 & 0 & 0 & 0 \\
8 & 1 & 0 & 1 \\
\hline
\end{tabular}

Adopted children were present in twenty-two percent of the transm racial fanilies, as compared to thirty percent of the control families. This conparison is shewn in Table XI.

\section{TABLF. XI}

PRESENCE OF ADOPTED CHILDREN PEIOR TO PIAACRATENT

\begin{tabular}{lccc} 
& Trensracial & Control & TotaI \\
\hline Present & 6 & 11 & 19 \\
Absent & 28 & 25 & 53 \\
Totsi & 36 & 36 & 72 \\
\hline$\left(X^{2}=.64\right.$ d.f. $=1$ not signirieant) & &
\end{tabular}


The difforence in fantitos' likelihood to have natural childrer was highly signiflcant. Natural children wero presont in 72 porcent of the transracial group, but in only 36 percent of the control group. Th1s compartson is shown in Table XII.

\section{TKBIE XIT}

DRFSENCE OF NATURAI, CHIIDREN PHIOR TO PLACEMANT

\begin{tabular}{lccc} 
& Transractal & Control & Total \\
\hline Prosent & 26 & 13 & 39 \\
Absent & 10 & 23 & 33 \\
Total & 36 & 36 & 72 \\
\hline$\left(X^{2}=9.46\right.$ d.f. $=1$ & $p<.01)$ & &
\end{tabular}

IX. RELIGIOUS AFFILIATION

The religious affiliations of the adoptive parents are listed in Tablo XIII. The control parents were all eithor Protestant (91.7 percent) or Catholte (8.3 percent). The transracisl group contajnod 58.8 porcent Protestants, 9.7 percent Catholtas, 1.4 percent Jews. 19.4 percent from other religions, and 11.1 percent had no religion. The homogeneity of Christismity among the control group was striking, as was the lack of such a tendency among the transracial group. who contained 32 percent parents from non-christian religions or no religion. This comparison is illustrafed in Tablo XIV and is highly significant. 
TALIE XIII

RFLICTOUS AFFITIATION OF ADOPTIVE PARENTS

\begin{tabular}{|c|c|c|c|c|c|}
\hline Renilgtor & $\begin{array}{l}\text { Thansracts } 1 \\
\text { Number }\end{array}$ & $\begin{array}{l}\text { parents } \\
\text { Percont }\end{array}$ & $\begin{array}{l}\text { Control } \\
\text { Number }\end{array}$ & $\begin{array}{l}\text { parents } \\
\text { Percont }\end{array}$ & Totel \\
\hline Protestant & 42 & 58.5 & 66 & 91.7 & 108 \\
\hline Catbolic & 7 & 9.7 & 6 & 8.3 & 13 \\
\hline Jawi.sh & 1 & 1.4 & 0 & 0 & 1 \\
\hline other* & 14 & 19.4 & 0 & 0 & 14 \\
\hline Nons & 8 & 11.1 & 0 & 0 & 8 \\
\hline Total & 72 & 100.0 & 72 & 100.0 & 144 \\
\hline
\end{tabular}

* 2 Ba'hai; 12 Unitarian

TABLE XIV

CHRISTIAN SND NON CHRISTJAN AFFILTATION OF ADOPTIVE PARENTS

\begin{tabular}{|c|c|c|c|}
\hline Affiliation & Transrecial & Control & TotaI \\
\hline $\begin{array}{l}\text { Christian } \\
\text { (Catholic, Protestant) }\end{array}$ & 49 & 72 & 1.21 \\
\hline $\begin{array}{l}\text { Jews, Unitarians, } \\
\text { Ba'haj. Nonbelievers }\end{array}$ & 23 & 0 & 23 \\
\hline Totsel & 72 & 72 & 144 \\
\hline
\end{tabular}

X. PERCETVED RELTGIOUS TNVOLVINENT

Four of the five partichpating afencies rated the couples on a four point scale of relighous involvoment. The rosults of that rating

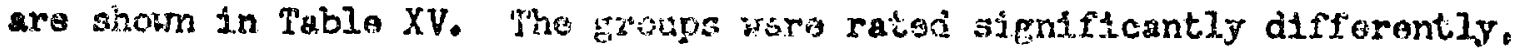


with the transracial adoptive Eroup seen more often as attending church regularly and perbaps being involved in extra participation, and the control groups seen more ofter as having no affillation or only nominal church membership.

TABIF IX

CASFNORKRR'S FSTIYATF OW COUPIAS' FELIGTOIS INVOLVEMENT

\begin{tabular}{|c|c|c|c|}
\hline Fistimato & Prerseractal & Control & Total \\
\hline $\begin{array}{l}\text { Not affiliated with } \\
\text { a church }\end{array}$ & it & 9 & 13 \\
\hline Nominal mombership & 1 & 9 & 10 \\
\hline $\begin{array}{l}\text { Membership, regular } \\
\text { attendance }\end{array}$ & 10 & 2 & 12 \\
\hline $\begin{array}{l}\text { Membership, regular } \\
\text { attendance, and } \\
\text { extra participation }\end{array}$ & 9 & 4 & 13 \\
\hline Total & 24 & 24 & 48 \\
\hline
\end{tabular}

XI. CHILORFN PLACRD IN ADOPTIVE HOMiS

Since two placements fri tihe control group wero double placements of siblings, the total number of children was 74. Only eight of these seventy-fou had any reported physical, omotional, or social problems in theit records. One child had been premature. mo had flat feet. Another had had a hernia corrected by surgery which was no longer a problem. One child was hinaej in uncomplicated, but had had an under-

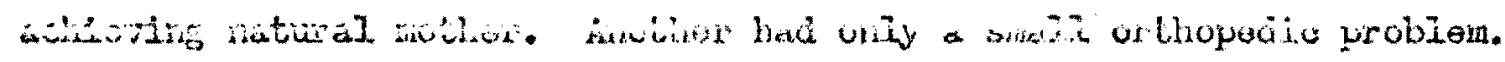


In only three cases djd the chlldrar appear to have serious problems at the time of placement. In one case, the child, ago two, had had serious physical problems. He had had coryoctjige surgery, but was left with some physteal handicaps. The other two childron wore eight and nine gears old sjblings who were reported to havo many soctal, acadende, and. behavioral problems.

All the othor childron placed wore haalthy, normal and usually joung. EMghty-seven percent of the Caucasian children (thirtymthroe) were under one year of age, and of these twonty etght, or seventy-three percent were two nonths or younger. The Nagro cheldren were somewhat. older. Flght of them (22.2 percent) were two months or younger: twenty-four of them (66.7 percent) were no more than two years old, and twalve (33.2 percent) wero ovor two, which is considered old age for adoptive children. Children pleced by age and agency aro show in Table XVI.

Eactly half (oighteen) of the Negro children were female, and half wore maj.e. In the control group of Cancastun children, there wero seventeen males and twenty-one females; 45 percent and 55 percent respectas tvely.

\section{GILDREN AWATTING ADOFTION}

Date on unadopted childron wore avajlable from the private agencies. but not from the public agansw. Information was obtalnod on thirty-two chtldron, wheza charectertstis tos suramarized in Table XVII. Chtldren with physleal ox developrontal probloms made up 40.6 percent of this group and the romatning $5 \%$ thenent wex normal children with no barriers 
TABIE XVI

CHILDREN PLACEO FOR ADOPTION IN 1968

BY AGE, AGENCI, AND RACIAL GROUP

\begin{tabular}{llllll}
\hline Group & 2 months & $2-12$ & $12-24$ & oldor than Total \\
& or loss & months months 24 months
\end{tabular}

Coritrol Semple

Waverly Home 90000009

Boys \& Girls Aid $11 \quad 0 \quad 1 \quad 0012$

Catholle Services $1 \quad 0 \quad 0 \quad 0 \quad 1$

$\begin{array}{llllll}\text { Welfare Comm. } 7 & 5 & 0 & 4 & 16\end{array}$

$\begin{array}{llllll}\text { Total } & 28 & 5 & 1 & 4 & 38\end{array}$

Transractal group

$\begin{array}{lrrrrr}\text { Waverly Homo } & 3 & 3 & 0 & 3 & 9 \\ \text { Boys \& Girls Aid } & 4 & 5 & 3 & 0 & 12 \\ \text { Catholts Sarvices } 0 & 1 & 0 & 0 & 1 \\ \text { Wolfare Comm. } & 1 & 7 & 2 & 4 & 14 \\ \text { Total } & 8 & 16 & 5 & 7 & 36\end{array}$

to placentent other than age or race.

Tho largest slingle group of unplaced children are normal, healthy chtldren of Negro ow part-llegro racial stock. Howover, the absolute number of such childiven is small, only ton, as coxpared to seven normal Caucestan chiliven who wore also awaiting adoption. No direct information ras avatiable as to kni long the children had awaitod homes. A sharp diitryence is stugested, hokever, by the agos of the children comprising 
TABLE XVIT

MILDREN AWAITING ADCPTION IN PRTJATE AGENCEES, DRC. 31, 1968

Children's Status
Chlldron with problens

Physical problems

N

Percent

Erain danage

7

21. 8

Promaturity

1

3.1

Slow development

2

6.2

Mental retardetion

2

6.2

1

3.1

Totax

13

40.6

Normal Chtldren. by race

Normal Caucasian

21.8

Noxmal Negro

10

$31 \cdot 3$

Normal, other race

2

6.2

Tatel

19

59.4

Grand TotaI

32

100.0

the respective groups. The Caucasiar children averaged fifteen days of geo and none wes moxe then tharty days old. The Negro chjldren avoraged 21.25 months, and rone uss less than thity days old. 


\section{CHAPTER V}

\section{DISCUSSION OF RESULPS}

\section{IMPLICATIONS OF THE STUDY}

Fducation. The unusually bigh level of educational achtevenent attained by the transracial group suggests several tings. First, Intellectual training and liberal sosial views have long boon knom to bo correlated. A personal committment to oqaluate poople on personal mertis rather than by racial stereotype way well be the result of ample education. Secondly, collsge campuses are often areas whare interaction betwon mowers of diferent paces occurs with grost froquancy. Intor aingling as equals and wosking tegether for a comon cause is much more Iikely whin the colloge expertaree than it is within ordinary community Iife. Thiraly. those Nogro pegplo allactod on colloge campuses aro vexy often drawn frox the middle clesses, and may, therefore, be expected to have many more characteristics, values, anj interests in common with the white students tho later came to mals up cus stody group. WIth such

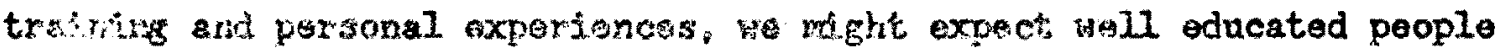
to lave woro poopting and posteve attitudos towexd black childran. Ircone. The findings of this study differ frow those of piovitus studies, The teansraclal group had notther mor nor loss income then ths entroi group or then the oregoi fopulfision. h nore important questicr methe have involved the stubility and socumty of income, as

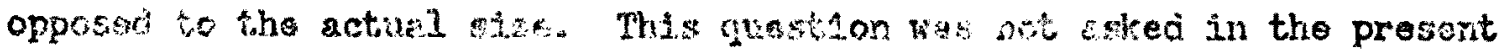


study. and deserves further investigation in future research.

Qccupation. A two-thinds majority of transractal fathers wero profossional men, a finding supporting the observations of provious studjes (Marmer, 1964; Branham, 1964; Roskies, 1963). This may be part of a general set of intercorrelsted interests: liberal ractal views, disinterest in monoy for its own sake, humantiarian valugs, and academic interests. On the other hand, it is possible that, having attalned prestige and status by way of professional position, theso fanfilies foel secure enough to risk more social pressures and far less likely to encourter them.

Afe. The findine of no difference in age contradicts both the early Ifterature that fourd transracis.l adoptive parents oldor and more recents statements that they are younger. On the one hand there is a widely held notion that youth is more concerned with racial injustice, and on the other the finding that transracial adoptive parents already have larger families, which takes time.

Cther Gildren. Those findings support the contention that transracial adoptive parents are nore likely to already havefulfilled the human desire to reproduce oneself. This theory, the "room-for-onem more" hypothesit, has been supported befors (Popper, 1966) in the sense that trensracial adoptivo pareris do tend to have more natural childron. The fact that. rithin these groups, there was not a tendency to have more adoptive children, but there was a signirtcant tendency to have more natural chtldren, does seem to suggest that aciopting black chtldren may be more likely for those who have alroady fulfillod thoir desiro

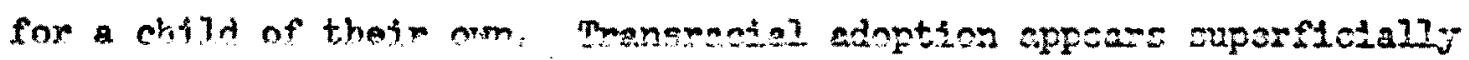


to be altruistic, but actualdy the motives seem to be dual.

A second idea way be important. Parenthood is an unknown area to rost prospective parents, whatever routo they nay choose to accomplish 1t. Perhaps the confidence gained from success in coping with one's own ehildren gives seasoned parents more courage to tackle a kind of parenthood complicatod by both edoption and sucial difference.

Religion. This study points to a conclusivaly higher Involvement In relfgious activity among the transractel gromp. It vould seam vary Hikejy that wo can safely infer \& religious notivo opersting to shape the decisions of these enuples to adopt traneractalin. Fowever, the hith portion of couples from churehes of a non-traditional character. and the relatively high number of coupies who clajned no religion suggest that the rolevant variable is likoly to bo moro philosophic than doctrinal. Other studies have suggested a hunanitarian value system operates in these decisions, and the findings from this study could be interpreted to support that contention.

\section{LINITATIONS OF THE STUIY}

Bistortcal Limitations. This area is changing at a very rapid prow. Findings frovi 1968 are elrosdy bocoming history rather than curront evonts. In periods of rapid trensition, it is essential to update studies of this kind frequently, and generalize from recent studien with cention.

Gootrephic Ifmtations. The prosent study presents a comprehenstvo viow of transracjal adoption of black ehticiron in 1968 in Cregon. Fs.ght

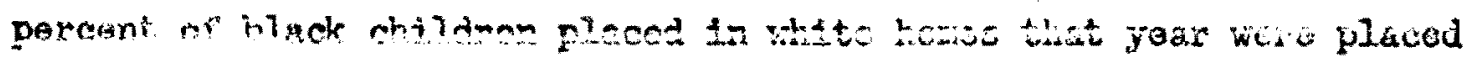
in the sisco (Opporturity. 1969). Cautions genersination to the 
country as a whole sppoars to bo justified, in viow of the extent to which this study confirms findings from Carada, Clicago, California end other regions.

\section{RECOMMFNDATIONS FOR FURIHER STUDY}

In order to keep abreast of rapidly changing events, and to widen the arsa of confident application, it is rocoumended that this kind of demographic study bo carrted out in other regjons in the future.

This stridy has raised a number of pertinent questions. To what extent do certain socioaconordic assets represant en onhanced capacity to meintein stability in oconomic resources and essure continued social support? These questions need further study so that the important undsrlyting Eactors can bo liestified. Cloarer understandine of these factors ts essential if more efficient recroitnent and applicant soreering is to sake placo.

Lastiv, we are only now reaching a time when enough placements of black obildren in white hones have been made, and the children have had timo nough living in thetr new homes, to make any evaluation of outcome. Past stidiss have shown demographic factors to be very ixportant In selection, and much less ingortant in adoptivs outcomo. These studies negd replication wibh this particular subgroup. After all, tho story has only begun with tho placement of a child. He and his now family hava a whole childhood ahosd to sharo. 


\section{BIBITOGRAPHY}

Eranhad. Ethel. Transractal aojoptionsomwen a 'good' family is not good enough. . Paper prosented at the National Conference of Social Work, Los engelas, Calliornia, May 26, 1964. Cited by G. W. Pepper. Interracjal ajoptions: family profilo, notivation and copirg methods. (Doctoral dissertation, liniversity of southern Cistornia) 1966

Doteiand, ionald Adoption research: an ovovicn. In Perspestives on

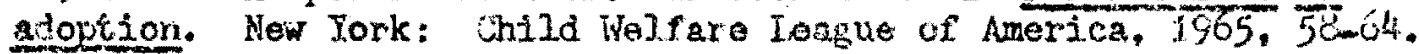

Cild Welfare Ieague of Arerica: Child Welfare League of Anarica Standsads for Aitoption Sertce. New York. 1959. (Rev. Ld.) 1969.

Elitor \& Publishar Maket Guide - 1968 Eaition. Population, income, housahold, Frm productsmoregon. New York: Editor and Publishor, 1968, p. 397 .

Falk, Inumonce I. A comperative study of transracial and inmracial edopt lons, Gild Welfare. $1970,49(2), 82-88$.

Fanshal, David. A study in Nago edoption. Wew York: Chld Nolfare Lespice of America, 1957.

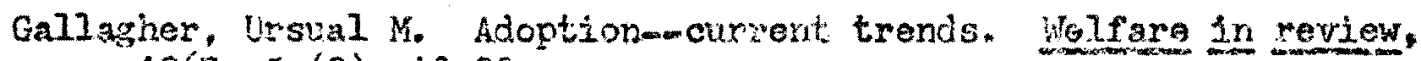
$1967.5(2), 12-20$.

Adoption resovees for blak ch \pm 1 dren. Children. $191,13(2), 40,50$.

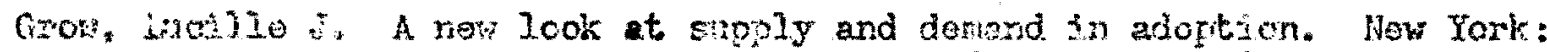

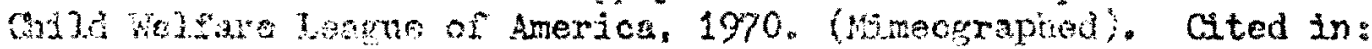

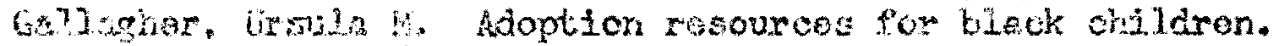
ginderer 1971,13 (a) $49-50$.

Hstos: Dizabeth, and Rose Rernstein. Why so fex Nerro achotions? (Mizion, 1965, 12 (1), 14m13.

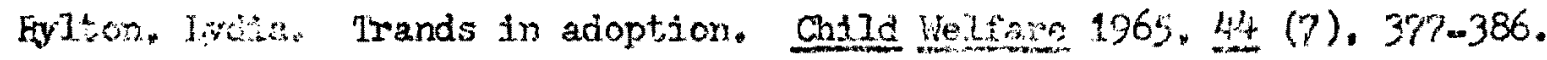

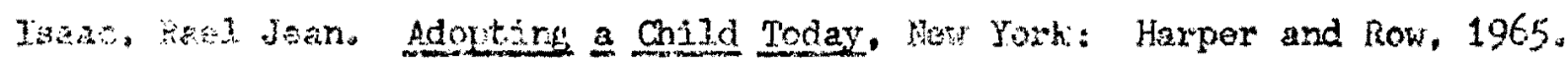

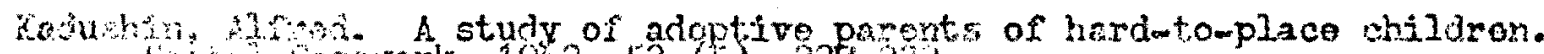

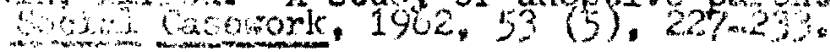


Mass, H. S. The successful adoptive parent applicant, Social Work, 1960. 2. 14.-20.

- and Engler, Rectard Fi, Jx. Chtidren in need of parents. Now York: Columbia Untversity Pross, 1959.

Marnon. Jude. Some psychodynarics of tranisacial adoptions. Paper presented at the Natjoial Conference of Soctal Nork, Ios ingeles, Celifinta, Way 26, 1964, citcd in Feppor. G. it. Interracjal adoptzons: fanily prople motivation and conje metroie.

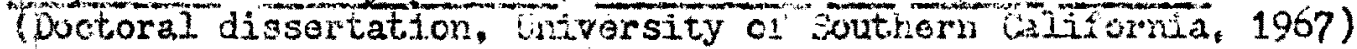

Witchell, Marion M. Transracial adoptions: pailosuphy and practice. Gild helfare, 1969. 48 613-619.

Opportumity. Ine. Adoption of olack childxen in 1969. Results of a survey of interractal ndoption in the United States in 1968. Portiand. Oregon, 19po. Hmeographed.

Partan. He Surveys. Polls, and Samples. Now York: Harpor \& Row, 1950.

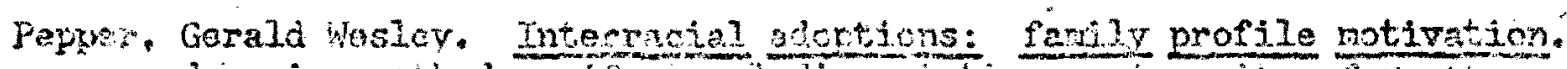

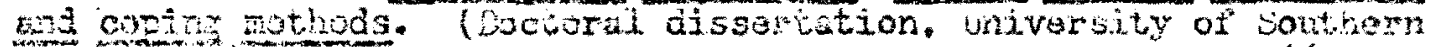

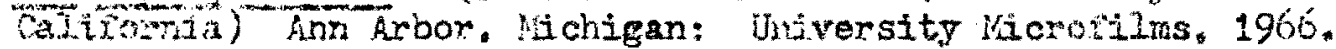
1io. $67+420$.

Priddy, Drow, and Doris KJmen. Characteriatics of whte couples who adopt bian-white children $\leq n$ the San Francisco Eay areama study of 24 poples. Haster's tiesis, Unirorsity of California. Eorkelew.

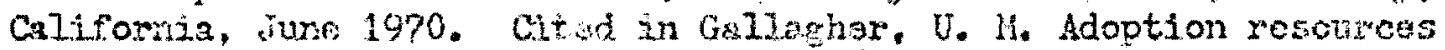
for black chjldren. Cnjldwor. 1971. 18, (2), 49-50

Riday, Fdind Supply and aman in adoption. Onild Gelfare, 1969. 48 (8). $489-491$.

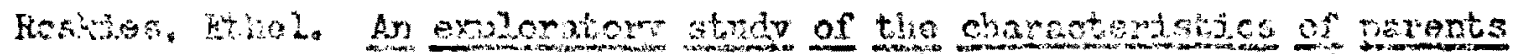

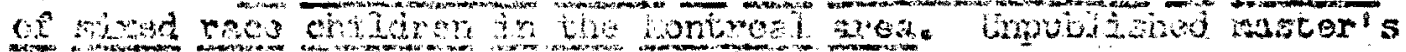

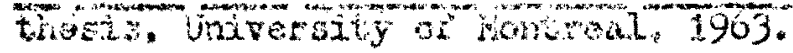

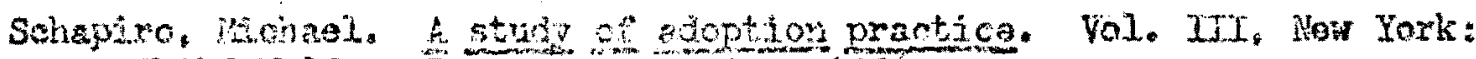

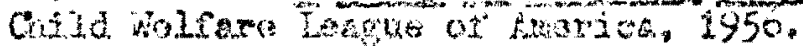

Sallews, Wartha. Tranclactal adoption. Child belare, 1969, 48 (6). 355.356.

Spears, yor F. Fransracial adortons in Canadem-wht howes for Indian

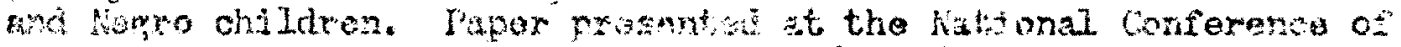

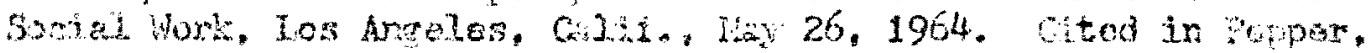

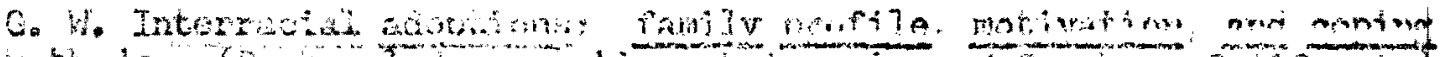

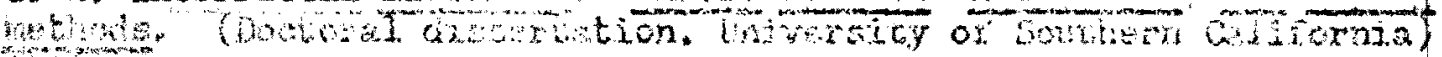
3,900 . 
Urited statos Buresu of Cencus. Stgtistteal sbstracts of the United Qtates. Washington, $D, C_{0}:$ W. S. Goterment Frinting of fice, 1970.

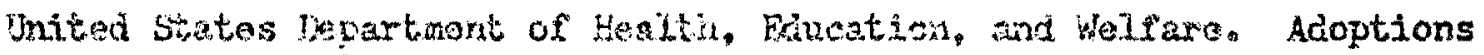

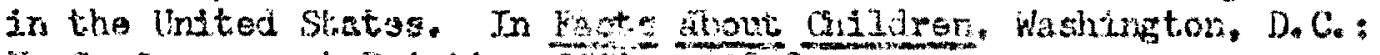
U. S. Govarnuent Printing offace, 1909 . 